\title{
ÓVODÁS KORÚ GYERMEKEK VÍZI FEJLESZTÉSE AZ ÉLMÉNYPEDAGÓGIA MÓDSZERÉVEL
}

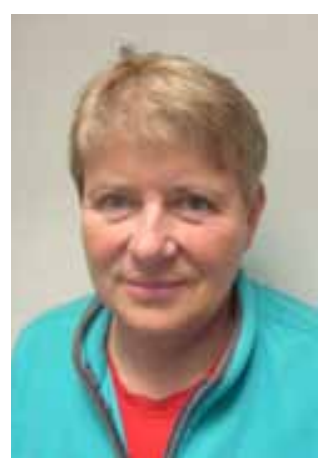

Szerző: DOC. PAEDDR. L'UBOMÍRA BENČURIKOVÁ, PHD. (*1957)

A pozsonyi Komenský Egyetem Testnevelési és Sporttudományi Kar, Úszás és Vízisportok Tanszékének oktatója. Az úszásoktatás elméletével és módszertanával foglalkozik.

e-mail: bencurikova@fsport.uniba.sk Fotók: SZERZŐ

Összefoglaló: Az élményszerü tanulás módszerének hatékonyságát 98 óvodás korú gyermek körében vizsgáltuk a mozgástanítás egyik specifikus területén, a vízhez szoktatásban. Eredményeink azt mutatják, hogy az oktatás során alkalmazott élményszerü oktatási módszer, melyet játékos, dalos, utánzó mozgásformákra és vízi játékokra építettünk, színesebbé tették a foglalkozásokat és hatékonyabbá tették a vízhez szoktatás gyakorlatanyagának elsajátítását. Ezt a tényt a kísérleti csoport siklásban nyújtott átlageredménye is bizonyítja, mely a kilépő tesztelések alkalmával jelentős javulást mutatott a kontroll csoport teljesítményéhez képest

$\left(p<0,01\right.$; Chi $\left.=4,268^{\star *}\right)$.

Kulcsszavak: óvodás korosztály, úszókészségek - siklás

Summary: In a group of 98 pre-school children, we investigated by innovative approach in the swimming didactic the effectiveness of swimming skills. The experimental factor was practice swimming skills with music. This factor has positively affected results of children in experimental group, compared to children in control group at the end of the swimming course $(p<0.01$, Chi $=4.268^{* *}$ ).

Key words: Pre-school age, Swimming skills - Flowing

\section{Bevezetés}

A hatékony pszichomotoros tanulás alapfeltételeit már óvodás korban a természetes mozgásminták megszilárdítása mellett az egyes sportágspecifikus alapkészségek elsajátítása jelenti. A sportági jellegű mozgások oktatása során a természetes mozgásminták alkalmazása a mozgáskoordináció fejlődésének egyik alapköve lehet ebben az életkorban (Macejková et al., 2008). A mozgáshoz kötődő pozitív érzelmi viszony korai gyermekkorban egyrészt a játékosság módszerével másrészt a pozitív élményszerzés módszerével is hatékonyan alakítható. A szerzők szerint az érzékszerveken keresztül történő tapasztalati tanulás során nemcsak a gyermek pszichomotoros képességei, hanem a felelősségteljes viselkedés és egyéb szociális kompetenciák is fejlődnek.

Hazai és külföldi kutatási eredmények szerint az óvodás korosztály esetében az alap úszókészségek hatásosan fejleszthetők a megfelelő oktatási módszer kiválasztásával, a fokozatosság betartásával és egy jól összeállított játékos gyakorlatanyag segítségével, hiszen ebben az életkorban az idegrendszer érési folyamatai lehetővé teszik az óvodás gyermekek gyors és hatékony mozgástanulását (Viczay Baráth, 2006, 2013). A releváns szakirodalom szerint a 4 - 6 éves korosztály esetében még nem beszélhetünk az egyes úszásnemek tanításáról, hanem inkább szoktatási folyamatról, az idegen közeghez való adaptálásról van szó (Benčuriková - Medeková, 2008). Az elmondottak alapján úgy véljük, hogy a tapasztalati, élményszerü tanulás gyorsabban elősegítheti a vesztibuláris, taktilis, vizuális és mozgásos analizátor alkalmazkodását a vizes közeghez, mely a kezdők számára idegen és szokatlan.

A fentiekben említett elméleti megfontolások alapján kutatásunk feladata az volt, hogy nagycsoportos óvodás gyermekek vízi fejleszthetőségének lehetőségeit tanulmányozzuk, és egyszersmind megvizsgáljuk az általunk kidolgozott mozgásprogram és a kiválasztott oktatási módszer hatékonyságát. Az úszás oktatásának hazánkban nincs egységesen elfogadott modellje, ezért a foglalkozásokon olyan eszközöket és módszereket ajánlatos használni, melyek kellő mértékben motiválják a kezdőt (Benčuriková, 2011).

Vízi mozgásprogramunk gyakorlatanyagának összeállításánál minden tanuló számára biztosítani szerettük volna a hatékony és élményszerű mozgástanulást, melynek fő célja az ún. alap úszókészségek elsajátítása volt. Módszereink közül az élménypedagógiát választottuk, mert úgy gondoljuk, hogy a vízhez szoktatás folyamatában a hagyományos oktatási módszereknek megfelelő kiegészítője lehet. Az élményszerü aktív tanulási mód egyrészt tapasztalatszerzésre másrészt csoportmunkára épül. A csoportos tevékenységek a gyermekeket együttműködésre, kommunikációra, problémamegoldásra, szokatlan környezethez való alkalmazkodásra késztetik. Az egyes foglalkozások tartalmát igyekeztünk úgy összeállítani, hogy azok tartós belső motivációt ébresszenek a gyermekekben és a vízben való tartózkodás minden alkalommal élményt jelentsen számukra. A játék a gyermekek pszichomotoros fejlesztésének elengedhetetlen eszköze. A zenés - játékos kísérleti mozgásprogramba ezért az óvodás korra jellemző játékos utánzó feladatokat, gyermekdalokat, kiszámolókat, mondókákat iktattunk be. A mondókák általában egyszerüek, dallamuk van, így mozgást, ritmust adnak a mozdulatsornak elősegítve ezzel a ritmusérzékelés fejlődését. A mondókák, dalok ritmikus szavalása közben ezek mesés tartalmát egyszerü, játékos mozdulatokkal játszattuk el a gyermekekkel.

A foglalkozásokon olyan segédeszközöket is használunk melyek hasznos tapasztalatokat nyújtanak és kiválóan alkalmasak az egyensúlyérzékelés a térérzékelés fejlesztésére, elősegítik a kinesztetikus észlelést (saját mozgás érzékelése) és javítják a szem-kéz és a szem-láb koordinációt (1, 2, 3 és 4 fotó). 


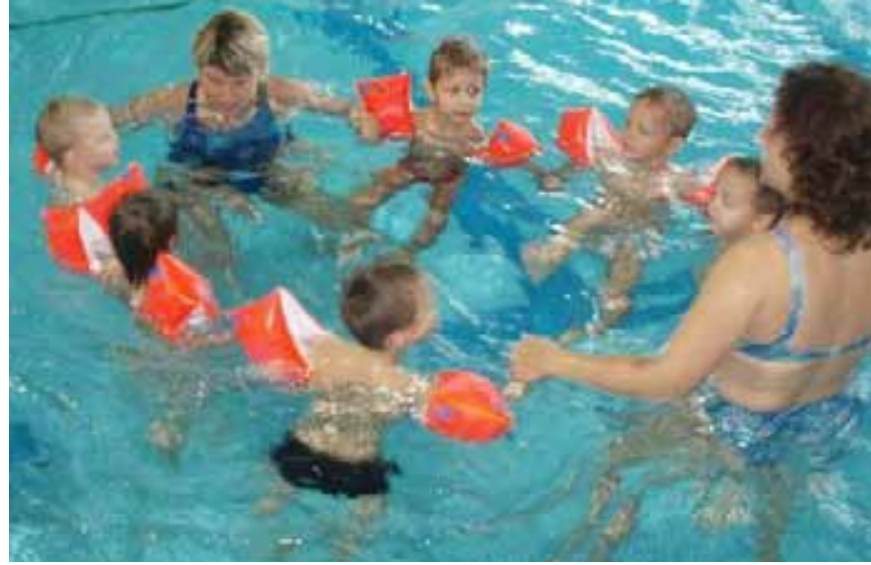

1. fotó: Karúszó

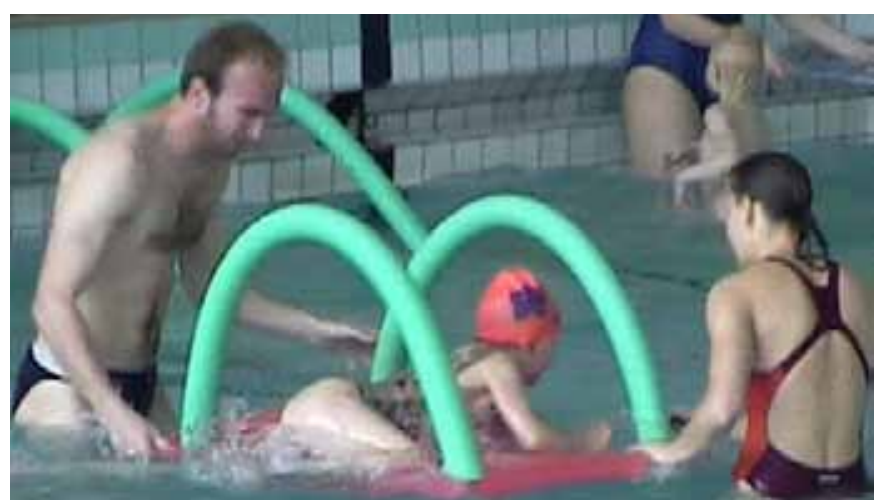

2. fotó: Akadálypálya

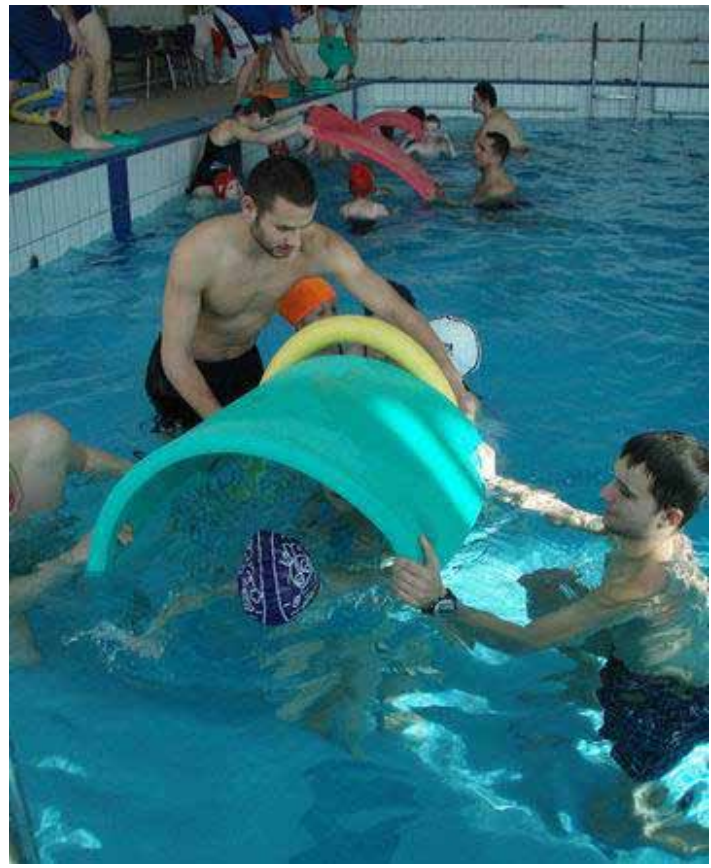

3. fotó: Alagút

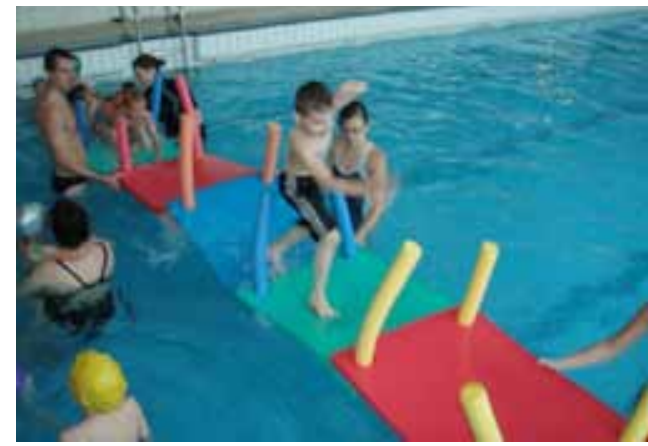

4. fotó: Híd (egyensúlyérzékelés fejlesztése)

\section{Cél, feladatok}

Kutatásunkban az élményszerű oktatási módszer hatékonyságának a vizsgálatát tűztük ki célul. Azt feltételeztük, hogy az általunk összeállított zenés mondókákra, vízi játékokra épülő mozgásprogram és a kiválasztott oktatási módszer hatására a kísérleti csoport siklásban nyújtott kilépő eredménye igazolhatóan jobb lesz a kontroll csoporthoz eredményéhez képest.

A kutatás célját, hipotéziseit valamint a vizsgált csoport életkori sajátosságait figyelembe véve feladatunk 1. a képességfejlesztő mozgásprogram kidolgozása, alkalmazása és értékelése, 2. a siklás kiinduló, majd végső szintjének felmérése, a változások értékelése valamint 3 . az eredmények összehasonlítása és értelmezése volt.

\section{Módszer}

A vizsgálatban összesen 98 óvodáskorú gyermek vett részt, ebböl a kísérleti csoportot $n=51$, a kontroll csoportot $n=47$ gyermek alkotta. A vízi fejlesztésben minkét csoport hetente egy alkalommal, 14 óra terjedelemben vett részt a pozsonyi testnevelési kar uszodájában, ahol biztosított volt a gyermekek életkorának megfelelő vízmélység és vízhőmérséklet. A tanfolyam fö célja az idegen közeghez való adaptáció kiváltása mellett a siklás és a többi vízbiztonsági alapgyakorlat elsajátítása volt. Az életkori sajátosságokat figyelembe véve minden foglalkozáson a gyermekek fejlettségi szintjének megfelelö, logikusan egymásra épülő játékos feladatokat alkalmaztunk.

A kísérleti csoportban a célgyakorlatok mellett a szakirodalom alapján (Csaba, 1994; Tóth, 2002; Viczay, 2005; Viczay - Baráth, 2006; Viczay-Kontra, 2015) olyan utánzó, játékos - énekes feladatokat és koordinációs gyakorlatokat végeztettünk a gyermekekkel, melyek a vízi mozgásprogram tartalmát játékos módon imitálták. A mozgásprogramba a vízi akadálypályán történő gyakorlást is beiktattunk, amit különösen kedveltek a gyermekek. Az akadálypálya egy olyan mozgássor elvégzésére adott lehetőséget, mely az alap úszókészségek fejlesztésére szolgált. Véleményünk szerint az akadálypálya használata a gyermekek kondicionális és koordinációs képességeit egyaránt fejleszti.

Az oktatás derékig érő vízben történt. Mivel a gyermekek örömmel használják a kéziszereket, minden foglalkozáson különböző színes vidám segédeszközöket használtunk, melyek elterelték a gyermekek figyelmét a félelemtől, és egyúttal megkönnyítették a feladatok végrehajtását.

A siklás készségének a felmérését mindkét csoportban az első és az utólsó foglalkozáson végeztük el. Ennek a tesztfeladatnak a segítségével azt mértük, hogy képesek-e a gyermekek elrugaszkodás után vízszintes testhelyzetben, a levegő visszatartásával minimálisan 2 métert hasonfekvésben siklani. A mérésnél Kiricsi (2002), Tóth (2002), Macejková (2008) és Benčuriková - Medeková, (2006) által javasolt teszt a kiválasztott populáció vizsgálatánál Szlovákiában viszonylag elfogadott és egyúttal kevésbé eszköz és időigényes. A siklásban nyújtott teljesítményt alternatív módon értékeltük: teljesítette és nem teljesítette. Adatainkat nemcsak a leíró, hanem a matematikai statisztika segítségével is elemeztük. 


\section{Eredmények}

Keresztmetszeti vizsgálatunk alapvető kérdése az volt, hogy vajon hogyan fejlődött a gyermekek siklásban elért teljesítménye 14 óra elteltével. Azt feltételeztük, hogy a kísérleti csoportban alkalmazott élményszerű oktatási módszer hatására a gyermekek siklásban nyújtott kilépő teljesítménye igazolhatóan jobb lesz ebben a tesztben, mint a kontroll csoport teljesítménye. A belépő és kilépő mérések eredményeinek összehasonlítását csoportonként az 1.ábra szemlélteti.

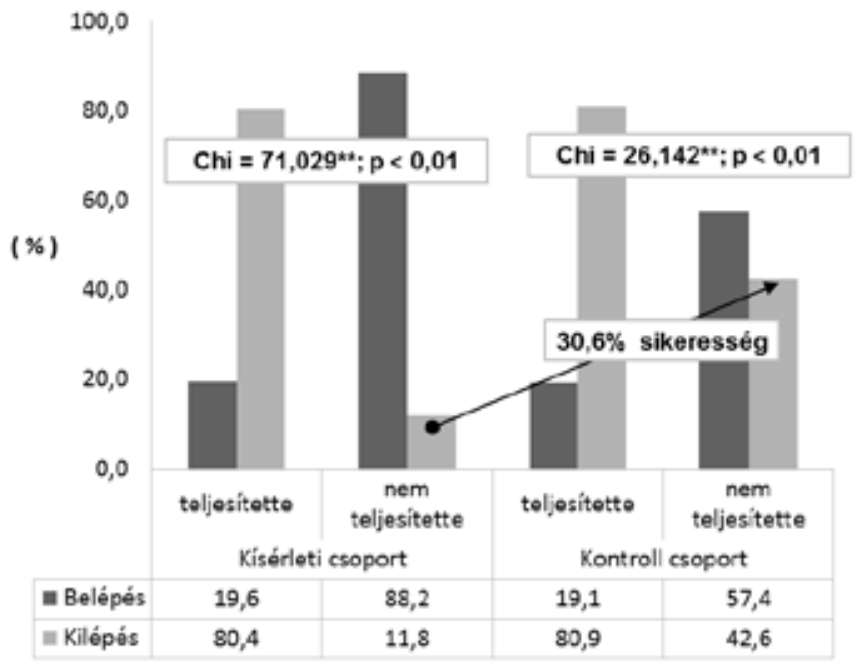

1. ábra: A siklás be- és kilépő eredményeinek összehasonlítása

A fenti ábrából kiderül, hogy ,belépéskor a vízben a vízszintes testhelyzetet a kísérleti csoportban levő gyermekek 88,2 $\%$-a, a kontroll csoportban pedig a gyermekek $57,4 \%$-a nem tudta felvenni. A tanfolyam elején a siklás gyakorlatát a kísérleti csoportban csupán a gyermekek 19,6\%-a, a kontroll csoportban pedig a gyermekek $19,1 \%$-a tudta csak végrehajtani. A belépő eredmények alapján elmondható, hogy a csoportok úszástudása a tanfolyam kezdetén közel azonos szinten volt. A siklás gyakorlatát sikeresen végrehajtó gyermekek esetében úgy véljük, hogy a szülöknek köszönhetően ezek a gyermekek rendelkeztek már bizonyos vízi előképzettséggel.

A tanfolyam befejeztével a siklásban nyújtott teljesítmény mindkét csoport esetében javult. A kísérleti csoportban a gyermekek $80,4 \%$-a volt képes elrugaszkodás után több mint 2 métert hason fekvés helyzetében siklani, míg a kontroll csoportban ugyanezt a feladatot a gyermekek 80,9 \%-a tudta sikeresen végrehajtani. A belépő és kilépő teljesítmény között említett pozitív változások mindkét csoport esetében jelentősnek bizonyultak. A kísérleti csoport kilépő átlagteljesítménye $p<0,01 \%$ - os szinten (Chi $=71,029)$, a kontroll csoporté pedig $p<0,01 \%$ - os szinten $(\mathrm{Chi}=26,142)$ volt jobb, mint a belépő mérések idején. A két csoport siklásban nyújtott kilépő teljesítményeit összehasonlítva elmondhatjuk, hogy a kísérleti csoport 30,8\% - kal igazolhatóan jobban teljesített az említett tesztben ( $p<0,01$; Chi=4,268), mint a kontroll csoport. Az említett eredmények alapján igazoltnak tekinthetjük feltételezésünket, miszerint az élményszerü oktatási módszer alkalmazása a kísérleti csoport siklásban nyújtott jelentősen jobb kilépő teljesítményét eredményezi a kontroll csoporthoz teljesítményéhez képest.

\section{Befejezés}

Összefoglalva megállapíthatjuk, hogy az élményszerü oktatási módszer pozitívan befolyásolta a kísérleti csoport siklásban nyújtott kilépő teljesítményét. Megerősítést nyert azon hipotézisünk, miszerint az általunk alkalmazott élményszerü oktatási módszer a vízi adaptációs mechanizmusokat pozitív irányba mozdítja el. Több éves gyakorlati munkánk során szerzett tapasztalataink és a mostani kísérletünk eredményei is azt tanúsítják, hogy egy jól összeállított játékos gyakorlatanyag és a megfelelő pedagógiai módszer segítségével az óvodás korosztály is képes elsajátítani a siklás gyakorlatát és a többi vízbiztonsági alapgyakorlatot és megfelelő mértékben képes alkalmazkodni a vizes környezet törvényszerüségeihez.

\section{Irodalom}

Benčuriková, L'. (2011). Vybrané faktory ovplyvňujúce základné plavecké zručnosti detí predškolského veku. Bratislava : PVC FF UK Stimul, 2011. 95 s. ISBN 978-80-8127023

Benčuriková, L'. - Medeková, H. (2006). Špecifiká hodnotenia plaveckých zručností u detí predškolského veku. In: Šport a kvalita života, (Brno: Masarykova univerzita, 2006), optický CD-ROM.

Benčuriková, L'. - Medeková, H. (2008). Az óvodás korosztály vízi képzésének tapasztalatai. In: Magiszter. ISSN 1583-6436, 2008, roč. 6, č. 2, s.101-109.

Csaba, L. (1994). A vízi játékok alkalmazásának lehetősége úszásban. In: Országos úszóedző konferencia, Budapest: 1994. MTE. ISBN 963716631 9, s. 49-56.

Kiricsi, J. (2002). Úszásoktatás kisiskolások számára. Budapest: SE-TSK, 2002, ISBN 963-430-080-4

Macejková, Y. (2008). Plavecké zručnosti v plaveckej lokomócii. In: Telesná výchova a šport, 18, č. 2, 2008, s. 29 - 32. ISSN 1335-2245

Macejková, Y. - Viczay, I. - Kontra, J.(2008). Koordinációs alapképességek vizsgálata 5-6 éves gyermekek körében. In: VI. OSK II.: Eger 28-30. október 2007. ISBN 978-96387701-3-4, s. 252-255.

Tóth, Á. (2002). Úszás, Oktatás, Sportági szakmódszertan. Budapest: SE-TSK kiadó, 184 p.

Viczay, I. (2005). A vízi játékok szerepe a vízhez szoktatás folyamatában, ISSN 1335-6445. In: Katedra, č. 7. s. 26-27. Viczayová, I. - Baráth, L. (2006). Poznatky a skúsenosti z predplaveckej prípravy detí predškolského veku. Nitra: SPU, 2006. 343 s. In: Telesná výchova a šport na univerzitách, ISBN 80-8069-802-3, s.297-303.

Viczay, I. - Baráth, L. (2013). Óvodás korú gyermekek vízi képzésének tapasztalatai. In: Katedra. ISSN 1335-6445, Roč. 20, č. 6, s. 26-27.

Viczay, I. - Kontra, J. (2015). Kisiskolás korú gyermekek úszástudásának és motoros képességeinek fejlesztése úszó foglalkozásokkal Szlovákiában. In: Iskolakultúra: pedagógusok szakmai tudományos folyóirata. ISSN 12155233, Roč. 25 , č. 4 . s. 62-77. 